\title{
A CULTURA MATERIAL ESCOLAR EM TRABALHO E EDUCAÇÃO. A MEMÓRIA FOTOGRÁFICA DE SUA TRANSFORMAÇÃO ${ }^{1^{*}}$
}

\author{
Maria Ciavatta*
}

\begin{abstract}
RESUMO
Este trabalho tem por objetivo resgatar a historicidade de alguns aspectos da cultura material de escolas do trabalho e das escolas profissionais e técnicas ou tecnológicas. Ele tem por base pesquisas que desenvolvi ao longo da década de 1990 e início dos anos 2000, buscando compreender como a relação trabalho e educação ganha forma e significado nas escolas que preparam pequenos e jovens trabalhadores para o trabalho, no contexto das relações sociais capitalistas e do desenvolvimento das forças produtivas. As fontes de pesquisa são documentos escritos e fotografias que provêm dos escassos arquivos das instituições e de arquivos públicos da cidade do Rio de Janeiro. A identificação de conteúdo, período e contexto foram objeto de investigação em documentos escritos e em entrevistas com ex-alunos e/ou professores ou ex-professores. As singelas ferramentas e aparelhagens eletromecânicas foram cedendo espaço a laboratórios e à aprendizagem de experimentos científicos com novos equipamentos e novas tecnologias.
\end{abstract}

PALAVRAS-CHAVE: Cultura material. Trabalho. Educação profissional. Fotografia

\section{ABSTRACT}

\footnotetext{
${ }^{1}$ Versão modificada e ampliada do trabalho apresentado em 21 de junho de 2008 na mesa coordenada intitulada "Escolas, escolarizações e utensilagens materiais" no VII Congresso Luso-Brasileiro de História da Educação realizado na Universidade do Porto, Portugal.

* Doutora em Ciências Humanas (Educação) pela Pontifícia Universidade Católica do Rio de Janeiro e Professora do Programa de Pós-Graduação em Educação da Universidade Federal Fluminense. Professora Visitante da Faculdade de Serviço Social da Universidade do Estado do Rio de Janeiro. Bolsista de Produtividade CNPq. E-mail:mciavatta@terra.com.br
} 
This paper aims to rescue the historicity of some aspects of material culture of work and vocational and technical schools or schools technology. It is based on research that developed during the 1990s and beginning of the 2000s, seeking to understand the relationship between work and education taking shape and meaning in schools to develop small and young workers to work in the context of capitalist social relations and the development of productive forces. The sources of research are written documents and pictures that come from the archives of the few institutions and public archives in Rio de Janeiro. The identification of content, time and context were the subject of research in documents and on interviews with former students and / or teachers or former teachers. The simple tools and equipment were electro-yielding space to laboratories and the learning of scientific experiments with new equipment and new technologies.

KEYWORDS: Material culture. Work. Vocational education. Photo

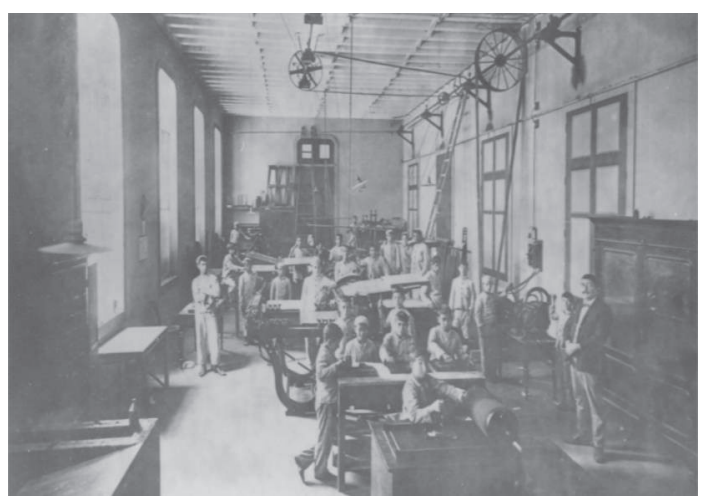

Fundação Casa de Rui Barbosa, 1908, autor desconhecido. "Instituto Profissional João Alfredo, Oficina de Marcenaria”.

\section{Introdução}

A aparente continuidade dos processos educativos no ensino formal não se confunde com as transformações que as escolas profissionais 
e técnicas sofreram ao longo do século XX. Este trabalho tem por objetivo resgatar alguns aspectos cultura material de escolas do trabalho e escolas profissionais e técnicas. Entendemos a cultura material como uma relação social que implica a materialidade, o simbólico e os significados dessa relação materializada nos objetos presentes nas escolas investigadas: Escola Técnica Estadual João Alfredo, Escola Técnica Estadual Visconde de Mauá e Escola Técnica Estadual Henrique Lage da primeira metade do século XX (denominações da época da pesquisa, CIAVATTA, 1993) e de centros federais de educação tecnológica do início do século XXI, (a exemplo do Cefet Química-Nilópolis), estado do Rio de Janeio (CIAVATTA, 2007).

O trabalho tem por base pesquisas que desenvolvi ao longo da década de 1990 e início dos anos 2000, buscando compreender como a relação trabalho e educação ganha forma e significado nas escolas que preparam pequenos e jovens trabalhadores. Parte do acervo fotográfico, constante desta apresentação provém de três escolas para crianças e adolescentes órfãos e desamparados aos quais era oferecida instrução primária e preparação para o trabalho manual. Outra parte reflete a introdução progressiva de novas máquinas e novos processos industriais que vão trazer mais complexidade ao ambiente escolar e aos fins da formação oferecida. Algumas das escolas profissionais foram transformadas em escolas técnicas e, depois, em centros de educação tecnológica. As singelas aparelhagens eletromecânicas foram cedendo espaço a laboratórios e à aprendizagem de experimentos científicos com novos equipamentos e novas tecnologias.

As fontes de pesquisa são documentos escritos e fotografias que provêm dos escassos arquivos dessas instituições e de arquivos públicos da cidade. A identificação de conteúdo, período e contexto foram objeto de investigação em documentos escritos e em entrevistas com ex-alunos e/ou ex-professores no caso das fotografias mais antigas. Informações complementares foram obtidas em entrevistas e observação participante no caso das fotos mais recentes.

Do ponto de vista teórico-metodológico, a área trabalho e educação tem como eixo a crítica à economia política que conduz a uma visão histórica da relação entre o mundo do trabalho e a educação, buscando-se compreender e reconstruir ao nível do discurso as diferentes mediações 
sociais constitutivas dessa relação em espaços e tempos determinados.

As pesquisas mostraram que tanto o trabalho, quanto a educação ocorrem em uma dupla perspectiva. $\mathrm{O}$ trabalho tem um sentido ontológico, de atividade criativa e fundamental da vida humana, e tem formas históricas, de exploração do trabalho humano, socialmente produzidas no espaço das relações sociais capitalistas. A educação tem seu sentido fundamental como formação humana e humanizadora com base em valores e em práticas ética e culturalmente elevados, e também ocorre em formas pragmáticas a serviço de interesses e valores do mercado.

Acompanhando as transformações econômicas e políticas da sociedade brasileira, a cultura material escolar se expressa pela uso diferenciado do espaço e de sua ocupação por professores e alunos; pelas diferenças nas atividades desenvolvidas, nos objetos produzidos e nos equipamentos e materiais didáticos. A escola do trabalho do início do século $\mathrm{XX}$ oferece uma educação assistencial de nível primário e prepara para o trabalho manual, artesanal e com o uso de máquinas simples (mecânica, eletricidade, marcenaria etc.). Progressivamente, com a industrialização dos anos 1930/1940 em diante, a escola assume a educação secundária, o ideário industrialista e transforma as oficinas nos moldes das fábricas. A pesquisa mais recente que estuda novas escolas de educação profissional, técnica e tecnológica, escolas de nível médio e pós-médio (tecnólogos), pari passu com o desenvolvimento científico-tecnológico, mostra que se introduzem equipamentos sofisticados de micro-eletrônica e de informática.

Mais do que os documentos escritos, a memória preservada nas fotografias expressa a mudança profunda na materialidade escolar, que acompanha, em cada época, a transformação dos processos produtivos impulsionados pelos objetivos de política educacional, pelo desenvolvimento científico-tecnológico e pela nova organização do trabalho.

No primeiro momento, faremos uma breve recuperação teóricometodológica de trabalhos que tratam da cultura material escolar e exporemos nosso referencial neste texto. A seguir apresentaremos imagens da cultura escolar de três escolas do trabalho, do início do século XX. Em terceiro lugar, veremos algumas imagens de instituições educacionais do presente em duas escolas com objetivos de formação técnica e tecnológica de nível médio e superior. 


\section{Revendo como se escreve a história da cultura material escolar}

A cultura material tem sido objeto de estudo de vários historiadores. Um dos textos seminais é de Le Goff (1990). Neste trabalho valemo-nos, principalmente, do dossiê publicado pela Revista Brasileira de História da Educação (da SBHE, n. 14, maio/ago. 2007), cujos artigos são resultado de pesquisas da década de 2000 e as referências bibliográficas, na quase totalidade, são trabalhos de autores brasileiros, portugueses e espanhóis publicados nos últimos anos de 1990 e nos anos 2000. Com base nesses dados, sem ter feito uma pesquisa exaustiva sobre as fontes bibliográficas, diremos que é um tema recente na história da educação no Brasil. Eles tratam de edifícios e seus espaços escolares, mobiliário, utensílios, materiais pedagógicos, manuais didáticos, troféus etc. Põem em cena também a ação dos professores e posturas corporais correlatas ao ambiente escolar.

O primeiro mérito dos trabalhos é o cuidadoso inventário dos objetos, móveis e equipamentos escolares que cumpre dois papéis principais: resgatar aspectos da memória das instituições, fazer aflorar aspectos da história de seu trabalho educativo, e valorizar a materialidade das instituições escolares, comumente, privadas de recursos materiais para realizar suas finalidades educacionais.

Os acervos são ricos de objetos esquecidos no tempo uns, de objetos ainda hoje presentes. Barra (2007), estudando órgãos da administração pública e professores das primeiras letras na Província de São Paulo, no século XIX, registra a solicitação de uma professora quanto ao mobiliário e aos utensílios de que necessita, no caso, para um espaço escolar doméstico: mesas, bancos, cadeira sobre um estrado, bancas, mochos, ${ }^{2}$ papel almaço, penas de aves, lápis de ferro, pautas, lousas, tinta, canivetes, traslados, ${ }^{3}$ catecismos, pedras, réguas, Gramática do Padre Ignácio Felizardo Fontes, cartas de sílabas, cartilhas, exemplares de leitura, tabuadas, campainha para a professora e outros objetos que não são comuns nos dias de hoje. ${ }^{4}$ Não reconhecemos, entretanto, nesses textos, a preocupação com a

${ }^{2}$ Mocho, aqui, significa um banco sem encosto, redondo ou quadrado.

3 Traslado, talvez, um aparelho para cópias.

4 "Bastardo, bastardinho para traslados de cada espécie"; "ditas de ferro" (p.22-23). 
contextualização sócio-econômica e política onde as escolas se situam, perdendo-se assim, o movimento da história dos sujeitos sociais da educação vivida.

Partindo da legislação educacional paranaense, relatórios de instrução pública e jornais paranaenses, Gisele de Souza (2007) discute a organização dos espaços e mobiliários dos estabelecimentos primários públicos, de modo especial os grupos escolares no estado do Paraná, nos anos de 1910. Revela um pouco de sua organização pedagógica e a cultura escolar entendida como "uma série de símbolos, estruturas, normas, pautas, tons, estilos, modos, códigos, costumes, tradições, formas de atuar, maneiras de pensar (MARTÍN, 2001, p. 20, apud op. cit., p. 39)".

Do ponto de vista teórico-metodológico, com o inventário dos objetos, prevalecem os procedimentos descritivos e a ênfase na subjetivação da interpretação. Compreende-se esse encaminhamento teórico que limita a compreensão do contexto social da materialidade implícita nos objetos escolares pela análise a partir de Chartier (2002) "quando este discute textos, impressos e leituras e apresenta a fertilidade da noção de 'apropriação' porque permite 'pensar as diferenças na divisão, porque postula a invenção criadora no próprio cerne dos processos de recepção"” (p. 136, apud op. cit., p. 45.).

Esses limites impostos pela teoria tendem a ser superados quando a autora reconhece, na presença dos móveis e utensílios, a disseminação de hábitos e costumes sociais nos alunos. Também quando identifica "a autorepresentação das elites como pedagogas da nação", instruídas, portadoras de civilidade, e as populações vistas "como portadoras de anomalias várias" (VEIGA, 2005, apud op. cit., p. 47),.Souza (op. cit.) conclui destacando a forte presença das autoridades da instrução pública "que deveria integrarse ao projeto de renovação dos costumes" como requeria o progresso da sociedade republicana (op. cit., p. 63). Chama a atenção para a figura do professor, que se mostra um personagem atuante, posicionado diante dos problemas concretos de sua escola.

Em alguns casos, a pesquisa de objetos é acompanhada de outras fontes documentais e logra-se captar o sentido e o significado desses recursos na realização de objetivos educacionais de gestores e professores. É o que anuncia Regina de Souza (2007a) estudando a 
Deutsche Schule em Curitiba, de 1884 a 1917, iniciativa comunitária de imigrantes alemães.

No texto, a autora busca realizar o estudo histórico da cultura material escolar. Reconhece "a organização hierarquizada do ambiente escolar, mas também sua vinculação com a sociedade mais ampla na qual a escola estava inserida", buscando suas práticas e seu cotidiano, a aceitação ou resistência às normas impostas. Tem por base que "os objetos pedagógicos são signos que expressam características da escola, de suas estruturas, processos e resultados" (ESCOLANO, 2000, p. 319, apud op. cit., p. 71).

No mesmo dossiê, Fiscarelli e Souza (2007), estudam os troféus escolares preservados na Escola Estadual Bento de Abreu em Araraquara, SP, de 1960 a $2004 .{ }^{5}$ A pesquisa inventariou mais de uma centenas de peças, entre as quais 103 troféus relativos a vitórias em competições esportivas, participação em concursos e festivais de bandas, fanfarras, teatro e desfiles de caráter cívico e cultural.

Alguns aspectos merecem ser destacados: primeiro, o mérito da escola, de seus gestores e professores, em preservar a memória e a história da escola nos troféus e em outros documentos (um total de 24 mil, datados a partir da década de 1930 ) que foram organizados pela equipe da pesquisa. Segundo, o cuidadoso trabalho no trato com os objetos e organização do acervo, objetos que ao tornarem-se documentos se tornam fontes de informação sobre a sociedade, suas transformações e sistemas de valores (op. cit., p. 97). Terceiro, o tratamento teórico-metodológico em termos de cultura material escolar, valendo-se de outras fontes para a análise dos troféus, buscando compreender as relações estabelecidas na preparação e participação da instituição nos eventos; inserindo a educação na realidade sociocultural, econômica e política, no processo de "desnaturalizr os objetos escolares recuperando sua historicidade compreendendo-os como produtos humanos, como objetos culturais com função e uso escolar" (p. 112), ou como "símbolos de excelência escolar" como anuncia o título do artigo.

\footnotetext{
${ }^{5}$ São as datas-limite citadas a partir dos objetos focalizados. Não sabemos se a pesquisa se estendeu além de 2004.
} 


\section{A cultura material escolar em trabalho e da educação}

Queremos introduzir, brevemente, o referencial teórico-metodológico que embasa a apresentação da memória fotográfica da cultura técnica material das escolas anunciadas. Alguns conceitos são básicos para o trabalho com a fotografia como fonte de pesquisa social: história, totalidade social, mediação, contradição, intertextualidade. ${ }^{6}$ Partimos de duas proposições principais. Em primeiro lugar, o método não se separa da construção do objeto. Significa que os fenômenos podem ser apreendidos de diferentes formas pelos pesquisadores, dependendo de sua visão de realidade e de como concebem a produção do conhecimento sobre essa mesma realidade.

Em segundo lugar, baseamo-nos na afirmação de que a reconstrução histórica de um fenômeno deve estar voltada para a história como processo, e a história como método (LABASTIDA, 1983). Na primeira afirmação, trata-se da história como realidade externa, ontológica, a produção da existência, a vida dos seres humanos em sociedade (MARX, 1979); na segunda asserção, trata-se de reproduzir os processos históricos no nível do pensamento e do discurso, como concreto pensado, objeto de reflexão teórica (MARX, 1977).

Neste sentido, a totalidade social construída nãoé uma racionalização ou modelo explicativo, mas um conjunto dinâmico de relações que passam, necessariamente, pela ação de sujeitos sociais. Não sendo apenas uma concepção mental, o conceito de totalidade social tem um referente histórico, material, social, moral ou afetivo de acordo com as relações que constituem determinado aspecto da realidade. Consequentemente, as totalidades são tão heterogêneas e tão diversificadas quanto os próprios fenômenos investigados. As mediações são processos sociais complexos que permitem compreender os fenômenos não apenas enquanto objetos isolados ou na sua aparência, mas na sua historicidade no tempo e no espaço, portanto, no movimento da história e de sua transformação, com as conquistas e contradições que ela implica.

No plano histórico, precisamos distinguir as mudanças ou rupturas, que mudam a natureza das relações sociais e do modo de produção vigente

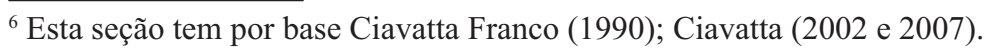

Educ. e Filos. Uberlândia, v. 23, n. 46, p. 37-72, jul./dez. 2009. 
das mudanças que trazem alterações, porém, mantendo a velha ordem social. Essa distinção nos permite compreender como as diversas formas de trabalho e de vínculos laborais, assim como as mudanças nos espaços escolares de acordo com as exigências e valores da ordem produtiva e da ordem social..

Não desconhecemos as tensões e problemas que o próprio materialismo histórico oferece desde sua gênese (ANDERSON, 1985; KONDER, 1992) e, sobretudo, os diversos descaminhos políticos trilhados ao longo de mais de século e meio sob sua inspiração. Também não ignoramos as dificuldades intrínsecas de operar analiticamente com as suas categorias fundamentais, o que não significa ignorar a existência de outros referenciais críticos ou não ao capitalismo. Uma leitura atenta das análises positivistas e funcionalistas nos indica um intenso embate interpretativo da realidade por diferentes grupos ou frações da classe burguesa e de seus intelectuais, muitos dos quais naturalizam as relações capitalistas, perdendo a possibilidade de entender as funções e disfunções internas destas relações e o que as produz.

Consideramos as fotografias mediações históricas dos processos educativos que preparam para o trabalho. Elas registram atividades que se enraízam nas relações sociais mais amplas, na totalidade social em que se articulam. Recuperando os vínculos da fotografia com os momentos históricos, Kossoy (1989) lembra que:

Toda fotografia é um resíduo do passado. Um artefato que contém em si um quadro determinado da realidade registrado fotograficamente. $\mathrm{Se}$, por um lado, este artefato nos oferece indícios quanto aos elementos constitutivos (assunto, fotógrafo, tecnologia) que the deram origem, por outro, o registro visual nele contido reúne um inventário de informações daquele precioso fragmento de espaço/ tempo retratado. $\mathrm{O}$ artefato no seu todo, assim como o registro visual na sua individualidade, constituem uma fonte histórica" (p. 30-31).

Em outros termos, significa reconhecer a fotografia como resultado da atividade social, o visível revelado e o invisível oculto, a história sob a aparente simplicidade de uma representação, a imagem. Mas "a 
história é o mundo das mediações" (CURY, 1985). Entender a fotografia como mediação significa concebê-la como processo social complexo (CIAVATTA, 2002), síntese de múltiplas determinações ou o concreto pensado (MARX, 1977, p. 229). A fotografia como mediação é uma visão historicizada de objetos singulares ou de acontecimentos, fenômenos cujo conhecimento deve ser buscado no conjunto articulado de relações sociais (estéticas, culturais, econômicas, políticas etc.) que o constituem no tempo e no espaço.

Mas a fotografia não fala por si sobre tudo que oculta além de sua sedução, da aparência sensível, estetizada com que se nos apresenta. Necessitamos de outras fontes documentais para identificá-la no tempo e no espaço, de modo a saber quem a produziu, a preservou, como está sendo utilizada, com que finalidades. Precisamos proceder a um processo de intertextualidade, isto é, de leitura das fotos recorrendo a outros textos para sua compreensão como fonte histórica.

Um procedimento recorrente é o recurso à história oral. Depoimentos e entrevistas como fontes históricas, contam hoje com razoável literatura e ampla discussão sobre seu estatuto científico. Em termos breves, Ferreira e Amado, (1996) consideram que a situação de entrevista entre o pesquisador e o entrevistado leva o historiador "a afastarse de interpretações fundadas em uma rígida separação entre sujeito/ objeto de pesquisa, e a buscar caminhos alternativos de interpretação". As entrevistas são fontes de informação, revestem-se de aspectos simbólicos, incorporam a subjetividade, as emoções e o cotidiano (p. xiv e xv).

\section{Das Escolas do Trabalho aos Centros Federais de Educação Tecnológica}

Duas são as temporalidades focalizadas neste trabalho: as primeiras décadas do século XX (1900 aos anos 1940) e o início do século XXI (os anos 2000). O tema memória e temporalidades evoca realidades que se complementam na análise dos fenômenos sociais: a relação estreita entre a estrutura econômica (o tempo longo do capitalismo), as diversas conjunturas econômicas e políticas (o tempo médio dos governantes e da sociedade em cada momento histórico), os discursos e as ações que 
concretizam a direção do movimento da história que se expressa no tempo breve dos acontecimentos (BRAUDEL, 1992). Neste trabalho, dentro do tempo longo do capitalismo, focalizamos duas conjunturas: o tempo médio do início das escolas do trabalho no país, o ensino artesanal, o início da industrialização; e a conjuntura de sua atualidade, tempo de avanços científico-tecnológicos e de nova organização do trabalho. A comparação somente é possível salvaguardando a especificidade social e educacional de cada conjuntura, remetida à totalidade social do tempo do capitalismo e das transformações no mundo da produção.

Nas primeiras décadas do século XX, o trabalho e o assistencialismo constituem os fundamentos dos processos educativos associados à "escola do trabalho" segundo dois eixos fundamentais: a regeneração pelo trabalho e o trabalho para a modernização da produção. Ao primeiro, prendem-se as iniciativas assistencialistas que vêm do século XIX, a filosofia educacional da obra de João Pinheiro e a rede de Escolas de Aprendizes e Artífices criada em 1909, a qual tinha por base atender, também, às necessidades da indústria e e serviços da época.

No segundo eixo, incluir-se-iam, ainda, o projeto do Deputado Fidélis Reis nos anos de 1920 e as iniciativas dos empresários paulistas que, também, na mesma década, criaram as bases do que viria a ser o Centro Ferroviário de Seleção Profissional de São Paulo (Cefesp) o qual teve importância fundamental no treinamento de operários para a indústria, nas fábricas, no modelo das futuras escolas do SENAI (Serviço Nacional de Aprendizagem Industrial) e da rede de escolas técnicas federais, ambos projetos sancionados em lei, em $1942 .{ }^{7}$

Do final do século anterior até as primeiras décadas do século XX, como o trabalho, a educação elementar fez na parte da questão social, isto é, da problemática da pobreza e da necessidade de disciplina para o trabalho e pelo trabalho, para se manter a ordem social. De um lado estão as necessidades da modernização e da ordem, consideradas necessárias ao novo momento, de outro, estão vários elementos ideológicos latentes nesse processo. A ideia de "regeneração pelo trabalho" ou o trabalho e a

${ }^{7}$ Decreto-lei n. 4.048 de 22 de janeiro de 1942, que cria o Serviço Nacional de Aprendizagem Industrial (SENAI) e o decreto-lei n. 4.073 de 30 de janeiro de 1942, a Lei Orgânica do Ensino Industrial, que dá início à rede das Escolas Técnicas Federais. 
educação como temas de "salvação nacional" são temas reiterados pelo governo Vargas (1930-1945).

A desagregação da sociedade agrária e escravocrata e a passagem para uma sociedade urbana e industrial vai recuperar a idéia de regeneração da sociedade, do tecido social a partir de diversas fontes: da idéia iluminista de progresso ou do "progressos" inevitáveis da razão e da espécie humana, da civilização do trabalho instaurada pela Revolução Industrial, do pensamento positivista e do pensamento metafísico-religioso, ambos conservadores da ordem social existente (CIAVATTA FRANCO, 1990).

A partir da Revolução de 1930, o país entra em outra fase de desenvolvimento econômico: a modernização e o processo de industrialização se tornam política do Estado. Seguindo as tendências mundiais, as empresas se modernizam com base na mecânica e na automação, nos processos tayloristas-fordistas da organização do trabalho. Este modelo se aprofunda com o desenvolvimentismo dos anos 1950 a 1970, a entrada de capitais estrangeiros, sua associação com empresas nacionais e a progressiva internacionalização da economia que ganha novos mecanismos sob a inspiração das políticas neoliberais a partir dos anos 1990, com o governo Fernando Henrique Cardoso e seus desdobramentos no governo Lula.

Já no início dos anos 2000, nos deparamos com estruturas produtivas avançadas, nova base técnica do trabalho, informática microeletrônica. Produzem-se robots, máquinas informatizadas que, como nunca, podem aumentar a produtividade e a qualidade da produção, prescindindo de milhões de braços e cérebros e ampliando a exploração e a precarização dos vínculos de trabalho, a pretexto da flexibilização dos processos produtivos. No plano das políticas educacionais tivemos uma nova lei da educação, a Lei de Diretrizes e Bases da Educação, Lei n. 9.393/96, e dois decretos ainda em processo de realização na educação profissional técnica e tecnológica, o Decreto n. 2.208/97 e sua revogação pelo Decreto n. 5.154/04. ${ }^{8}$

O capital dinheiro descola-se cada vez mais de sua referência real e torna-se fictício, especulativo, permitindo, aos que tem o manejo das

\footnotetext{
${ }^{8}$ Sobre o significado de cada um desses decretos e a polêmica instaurada, ver, entre outros, Frigotto, Ciavatta e Ramos, 2005.
} 
informações, auferir ganhos extraordinários, mesmo que seja às custas de milhares de trabalhadores em todas as parte do mundo, particularmente nas nações do capitalismo periférico (FRIGOTTO e CIAVATTA, 2006). A crise financeira de 2008 traz contornos ainda pouco conhecidos sobre o alcance de suas conseqüências para a vida social.

Selecionamos para a apresentação algumas fotos que mostram a cultura técnica material da formação profissional, conjugando a aprendizagem do trabalho e a educação profissional que se transforma pari passu com a indústria. A temporalidade das escolas e das fotos evidenciam materiais, atividades e distribuição espacial diversa dos móveis e utensílios, dos equipamentos, dos alunos e professores. Três escolas são mais antigas e as fotos revelam o mundo do trabalho do início do século XX. A quarta escola é apresentada na sua atualidade, primeira década do século XXI, provida de equipamentos de informática e processos avançados de análise química.

Agrupamos as fotos três primeiras escolas a partir de três temas: a assistência aos alunos provindos das classes pobres; $\mathrm{o}$ trabalho na atividade escolar: a formação geral/a formação profissional.

\subsection{A Escola Técnica Estadual João Alfredo - O antigo Palácio Rudge: Asylo dos Meninos Desvalidos e Instituto Profissional João Alfredo $(\mathbf{1 8 7 5})^{9}$}

Do início da alameda que conduz à Escola Técnica Estadual João Alfredo, divisa-se, no alto, o espaço amplo, saudável, iluminado da colina onde se situa o antigo palácio senhorial de grandes janelas abertas, onde foi instalado o "Asylo para os Meninos Desvalidos", mais tarde o Instituto Profissional Masculino, para os mais pobres, mais desamparados, na época de sua criação, em 1875, pelo Imperador D. Pedro II. Que controvertida consciência convivia com a escravidão e destinava um local de tanta aristocracia para abrigar os meninos mais pobres? O tipo de vida, que lhes era destinado pela instituição oficial, está registrado nos documentos

\footnotetext{
${ }^{9}$ As três escolas apresentadas são parte de Ciavatta, 1993. Por razões de espaço, suprimimos as legendas de contextualização das fotos que constam do trabalho original.
} 
escritos e na memória legada nas fotografias, ampliada pelos depoimentos daqueles que lá se educaram para o trabalho.

Perfazem ao todo 43 fotografias datadas de 1903 a 1927, sendo 13 dos anos dez; e as demais de data indeterminada. Quanto ao fotógrafo, 16 fotografias são de Augusto Malta e as demais (27) de autor desconhecido. Pertencem ao Museu da Imagem e do Som (MIS - Rio de Janeiro), ao Arquivo Geral da Cidade do Rio de Janeiro (AGCRJ) e à Fundação Casa de Rui Barbosa FCRB). As fotos estão organizadas em séries subseqüentes: o ambiente externo e os edifícios; pátios internos, suas atividades e ambientes correlatos; as dependências onde viviam os alunos; as atividades de cultura geral e de formação profissional. Os dados de identificação e as referências de que dispomos foram obtidos nas legendas do acervo do MIS e em entrevistas com ex-alunos e antigos professores.

\section{a) Assistência}

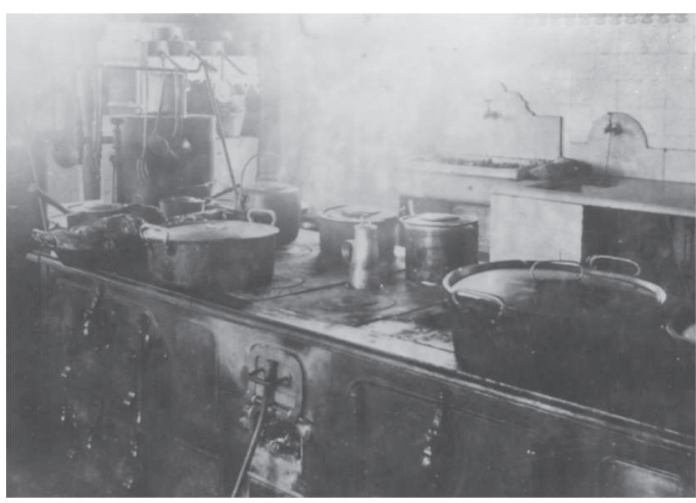

FIGURA 1 - Fundação Casa de Rui Barbosa, data indeterminada, autor desconhecido. Instituto Profissional Masculino. "Cozinha". 


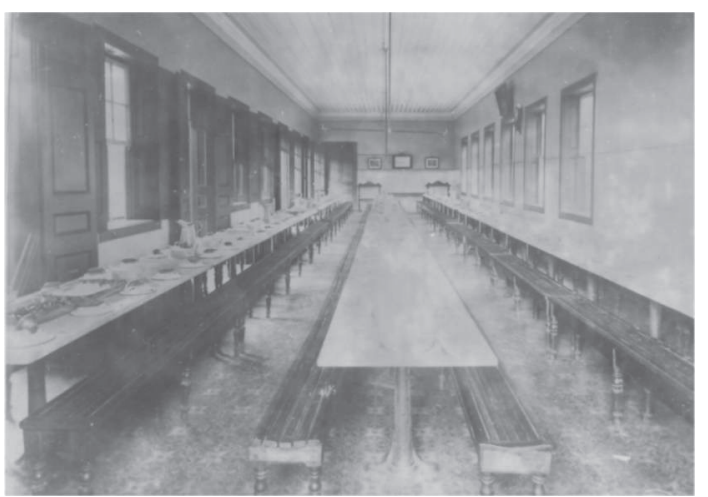

FIGURA 2 - Fundação Casa de Rui Barbosa, data indeterminada, autor desconhecido. Instituto Profissional Masculino. "Refeitório".

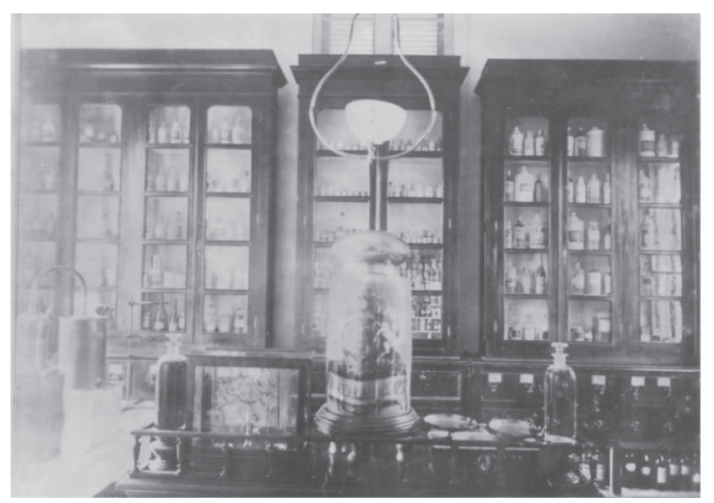

FIGURA 3 - Fundação Casa de Rui Barbosa, data indeterminada, autor desconhecido. Instituto Profissional Masculino. "Rouparia da Escola”. 


\section{b) Trabalho}

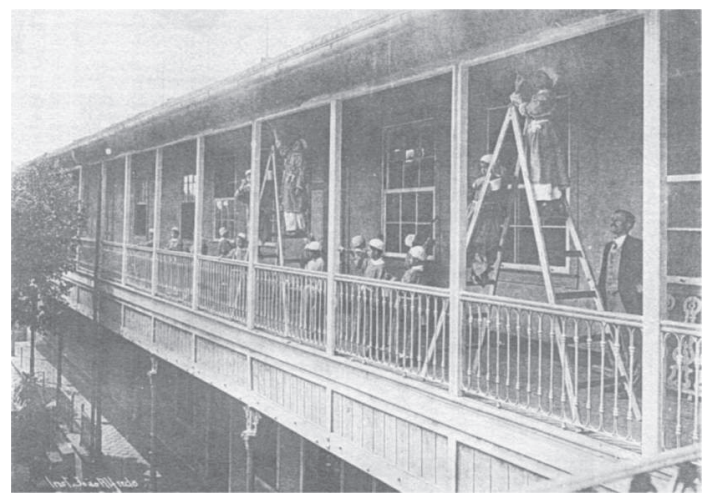

FIGURA 4 - Museu da Imagem e do Som. 28 de setembro de 1916, Augusto Malta. Instituto Profissional Masculino. "Pintura das grades da varanda da Escola pelos alunos".

c) Formação profissional

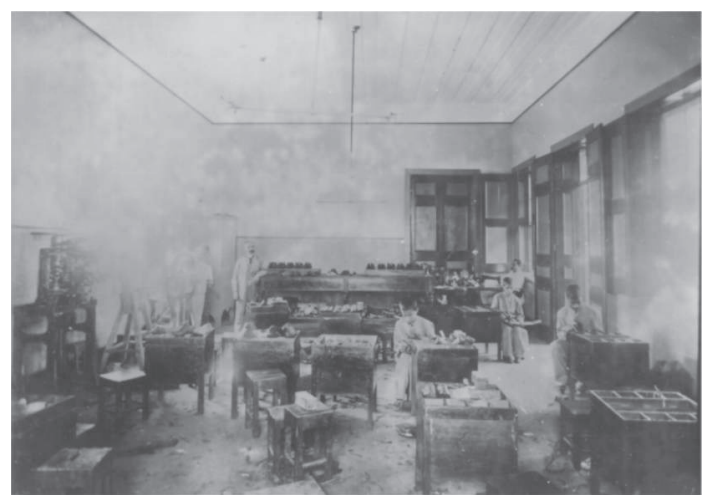

FIGURA 5 - Fundação Casa de Rui Barbosa, data indeterminada, autor desconhecido. Instituto Profissional Masculino. "Oficina de sapateiro". 


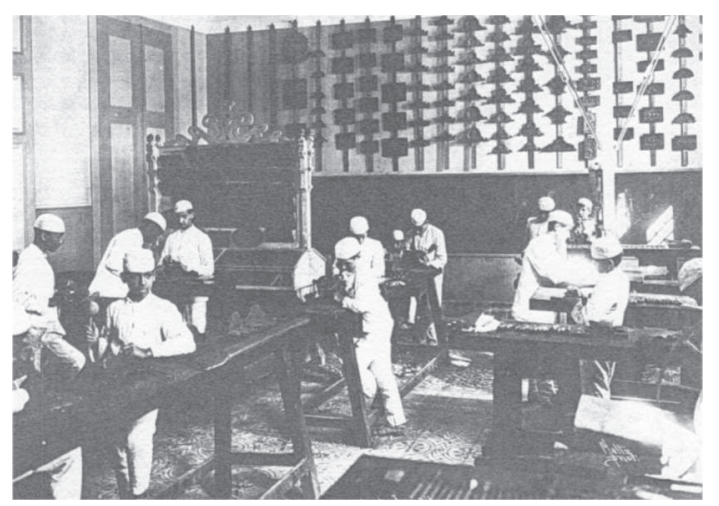

FIGURA 6 - Museu da Imagem e do Som, data indeterminada, Augusto Malta. Instituto Profissional Masculino (Colégio Estadual João Alfredo). “Aula de entalhação".

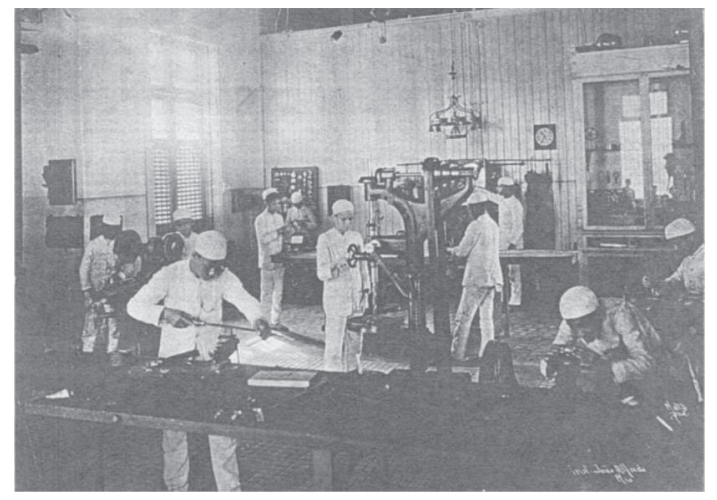

FIGURA 7 - Museu da Imagem e do Som, data indeterminada, Augusto Malta. Instituto Profissional Masculino. "Aula de eletricidade". 


\section{c) Formação geral}

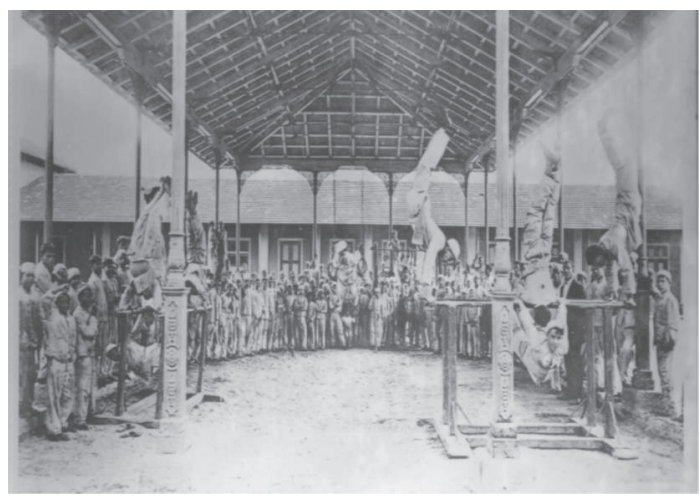

FIGURA 8 - Fundação Casa de Rui Barbosa, 1908, autor desconhecido. Instituto Profissional Masculino "Aula de ginástica"

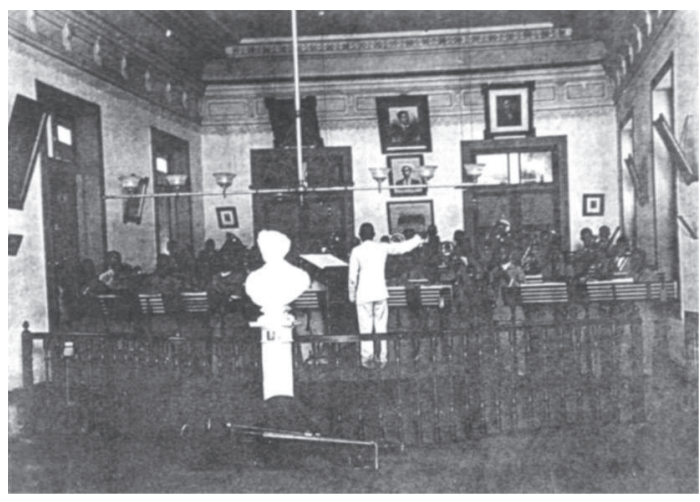

FIGURA 9 - Museu da Imagem e do Som, data indeterminada, Augusto Malta. Instituto Profissional Masculino. "Banda Musical". 


\subsection{A Escola Técnica Estadual Visconde de Mauá (1916)}

A Escola Técnica Visconde de Mauá situa-se em Marechal Hermes, distante subúrbio da cidade do Rio de Janeiro. Foi instalado em 1916 como Segunda Escola Profissional Masculina, na antiga oficina de preparação de materiais destinados à construção da Vila Proletária de Marechal Hermes. Na época em que fizemos a pesquisa (1991 a 1993), a escola não tinha arquivo disponível ("pegou fogo nos anos 1970", segundo um funcionário da Secretaria), salvo os documentos de matrícula, rendimento escolar, reprovações etc. dos alunos ${ }^{10}$. As fotos que utilizamos e sua identificação foi possível graças à generosa doação de um antigo ex-aluno e professor e às entrevistas que ele e outro professor nos concederam. A escola recebeu o nome de Escola Visconde de Mauá. em 24 de outubro de 1916.

$\mathrm{O}$ acervo cedido à autora pelo Prof. Guttman, ex-aluno e exprofessor de Mecânica do CTEVM (é composto por 31 fotografias). Posuui fotos externas do edifício, das áreas agrícolas, de animais, de construção e de produção de laticínios dos primeiros tempos da escola, piscina, refeitório, várias oficinas e salas de aula, banda musical, foto de pose do corpo docente, sala de reuniões.

\section{a) Assistência}

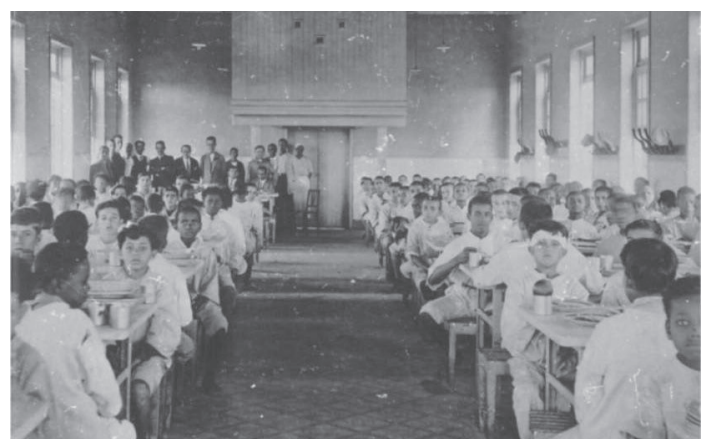

FIGURA 10 - Acervo Maria Ciavatta (Prof. Cristodolino

Guttmann de Souza), data indeterminada, autor desconhecido. Segunda Escola Profissional Masculina. "Refeitório".

${ }^{10}$ Recentemente, fomos agraciados com um dossiê de cópia de documentos jurídicoadministrativos sobre a Escola. 


\section{b) Trabalho}

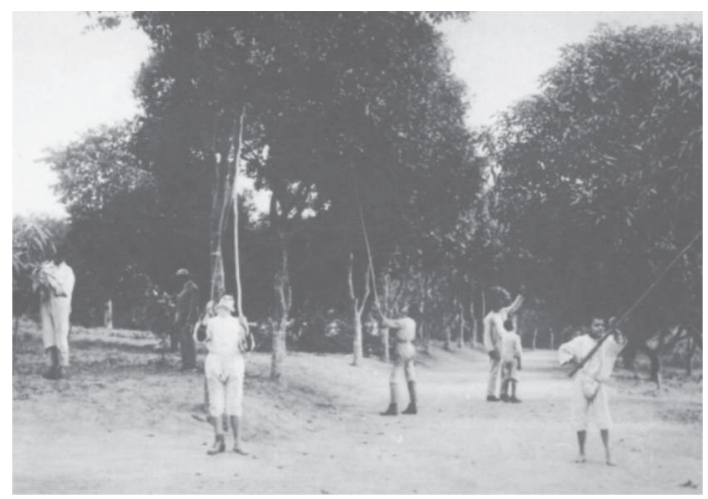

FIGURA 11 - Acervo Maria Ciavatta (Prof. Cristodolino Guttmann de Souza), data indeterminada, autor desconhecido. Segunda Escola Profissional Masculina. "Alunos fazendo a poda das mangueiras".

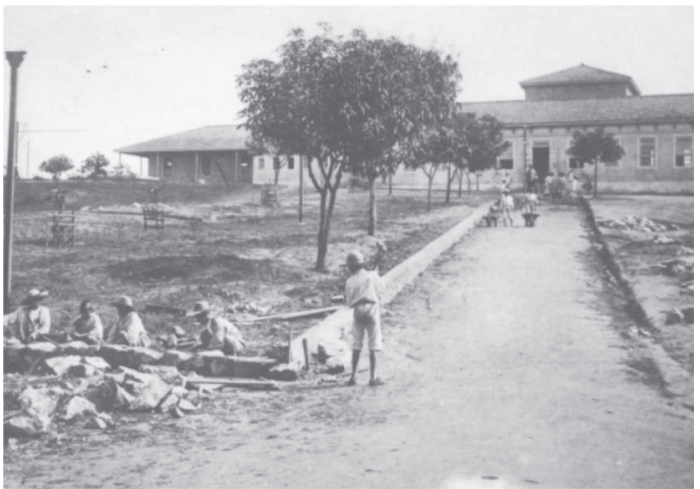

FIGURA 12 - Acervo Maria Ciavatta (Prof. Cristodolino Guttmann de Souza), data indeterminada, autor desconhecido. Segunda Escola Profissional Masculina. "Alunos fazendo a entrada da Alameda Barão Bianor de Lucas". 
c) Formação profissional

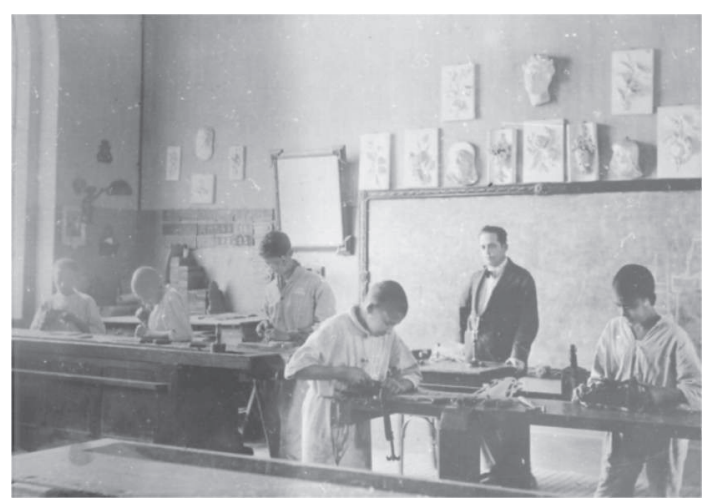

FIGURA 13 - Acervo Maria Ciavatta (Prof. Cristodolino Guttmann de Souza), data indeterminada, autor desconhecido. Segunda Escola Profissional Masculina.

"Sala de entalhação".

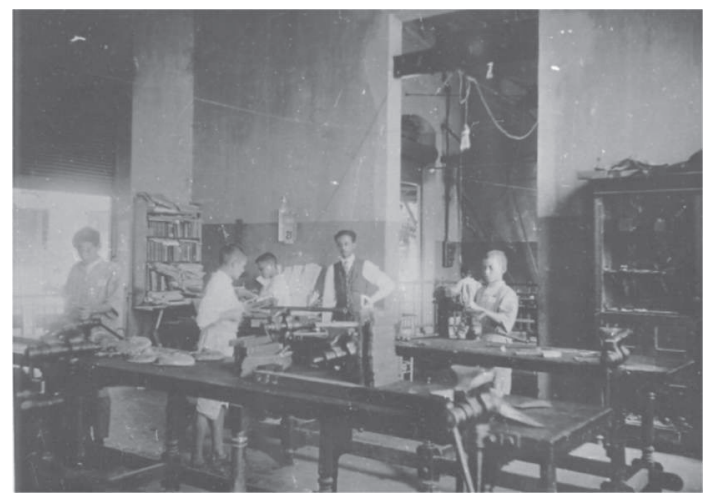

FIGURA 14 - Acervo Maria Ciavatta (Prof. Cristodolino Guttmann de Souza), data indeterminada, autor desconhecido. Segunda Escola Profissional Masculina.

"Oficina de Carpintaria". 


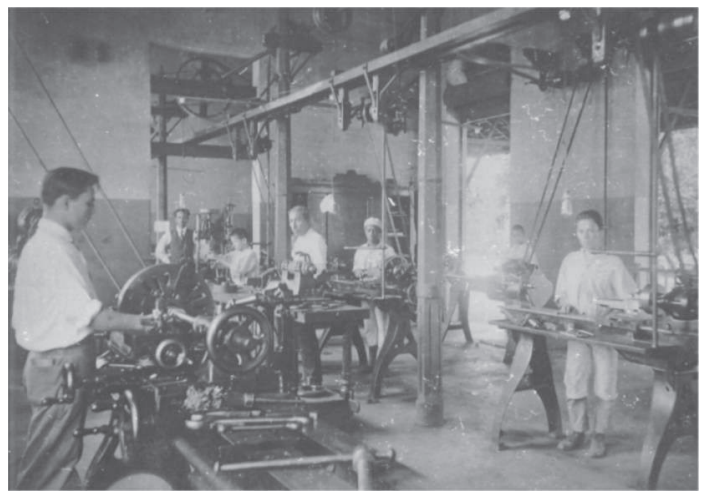

FIGURA 15 - Acervo Maria Ciavatta (Prof. Cristodolino Guttmann de Souza), data indeterminada, autor desconhecido. Segunda Escola Profissional Masculina. "Oficina de Mecânica".

\section{d) Formação geral}

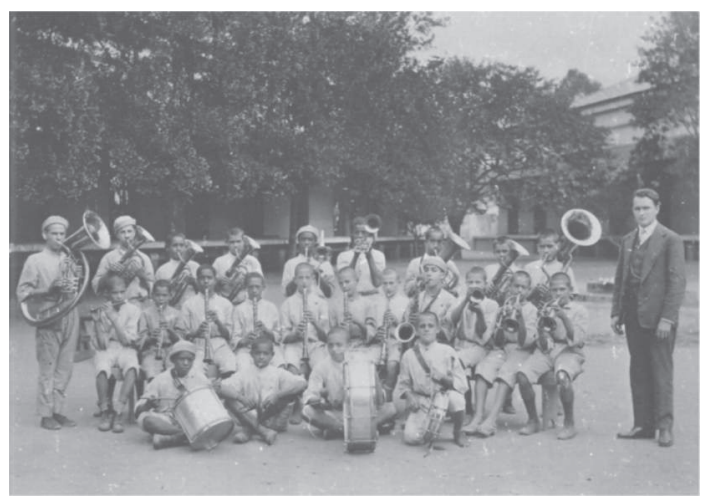

FIGURA 16 - Acervo Maria Ciavatta (Prof. Cristodolino Guttmann de Souza), data indeterminada, autor desconhecido. Segunda Escola Profissional Masculina. "Refeitório". 


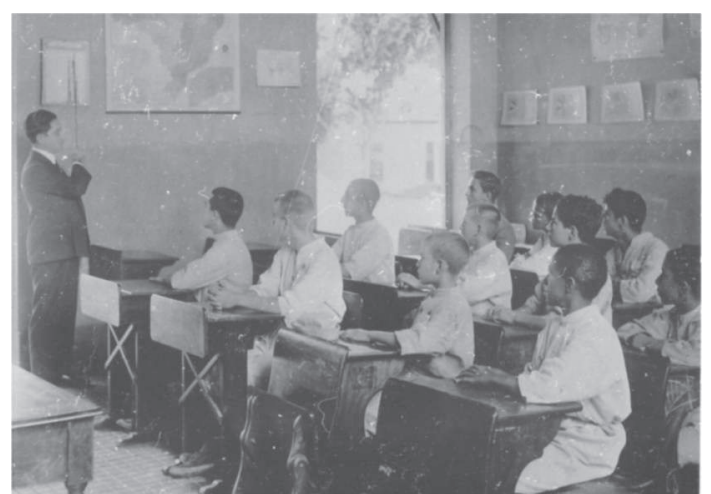

FIGURA 17 - Acervo Maria Ciavatta (Prof. Cristodolino Guttmann de Souza), data indeterminada, autor desconhecido. Segunda Escola Profissional Masculina. "Sala de Geografia".

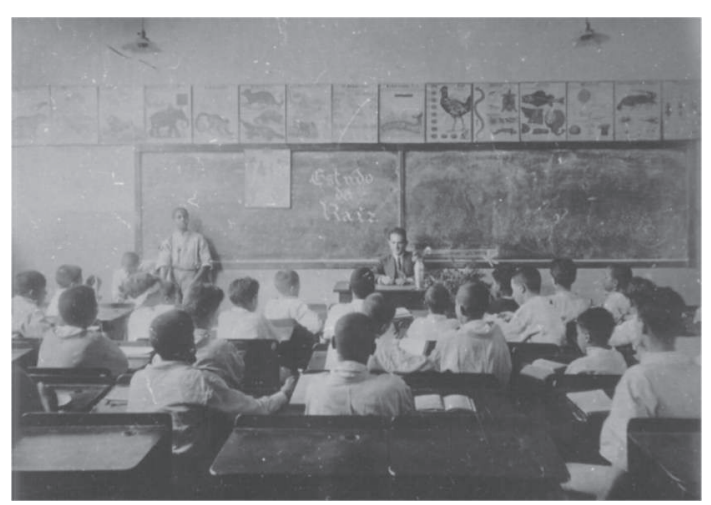

FIGURA 18 - Acervo Maria Ciavatta (Prof. Cristodolino Guttmann de Souza), data indeterminada, autor desconhecido. Segunda Escola Profissional Masculina. "Sala de História Natural". 


\subsection{A Escola Técnica Estadual "Henrique Lage" - Uma antiga Escola do Trabalho (1923)}

Situada no bairro operário do Barreto, perto da indústria naval em Niterói, estado do Rio de Janeiro, a antiga escola técnica foi criada como Escola Profissional Washington Luís, em 1923. Passou a Escola do Trabalho do Estado do Rio de Janeiro por ordem do Governo Provisório em 1931. Acompanhando o processo de industrialização, passou a Escola Profissional Henrique Lage em 1941 e a Colégio Industrial Henrique Lage em 1964.

As fotos, cedidas pelo Clube de História do Colégio, cobrem um período aproximado de 20 anos, dos anos 1920 ao final dos anos 1950. São 27 fotografias que mostram a cultura material de várias atividades da Escola: vistas externas, demolição de prédio antigo, diversas oficinas, exposições de trabalhos dos alunos, visitas de autoridades, palestra para os alunos, gabinete dentário, banda de música e o maestro, professores e alunos em pose em frente à escola, quadro de formatura, atividades de ginástica, desfile cívico.

\section{a) Trabalho}

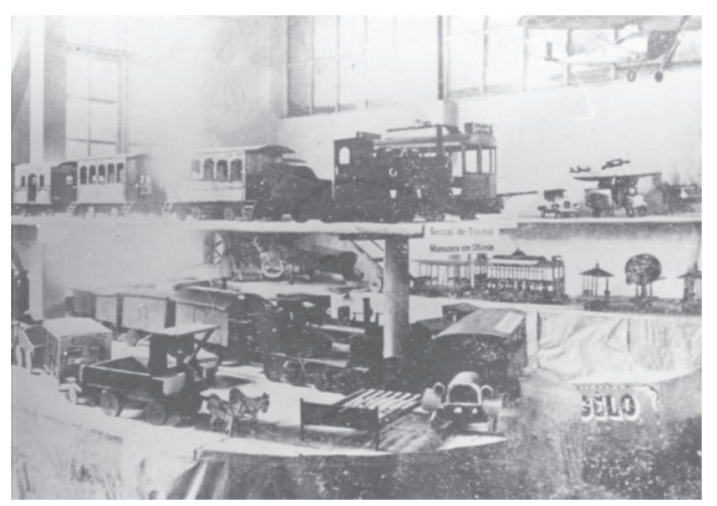

FIGURA 19 -. Acervo do Clube de História do CEHL, 1928, autor desconhecido. (Escola Profissional Washington Luís). "Exposição Anual da Escola, Seção de Trabalhos Manuais em Oficinas". 


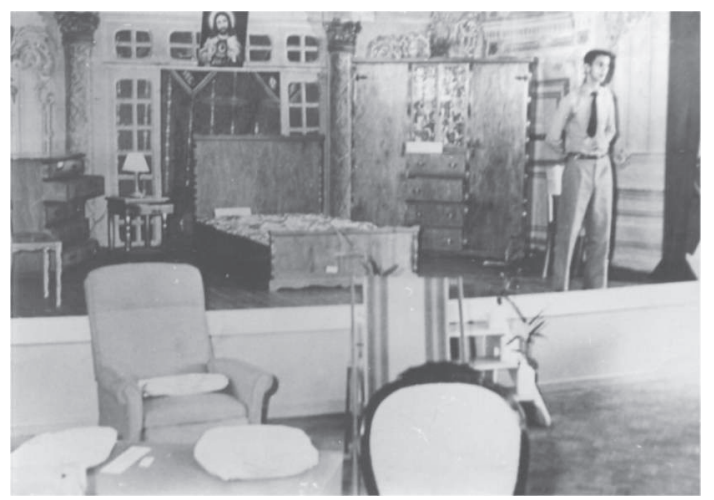

FIGURA 20 - Acervo do Clube de História do CEHL, Data indeterminada, autor desconhecido. (Escola Profissional Henrique Lage [?]). "Stand de móveis feitos pelos alunos durante uma exposição de trabalhos da Escola”.

\section{b) Formação profissional}

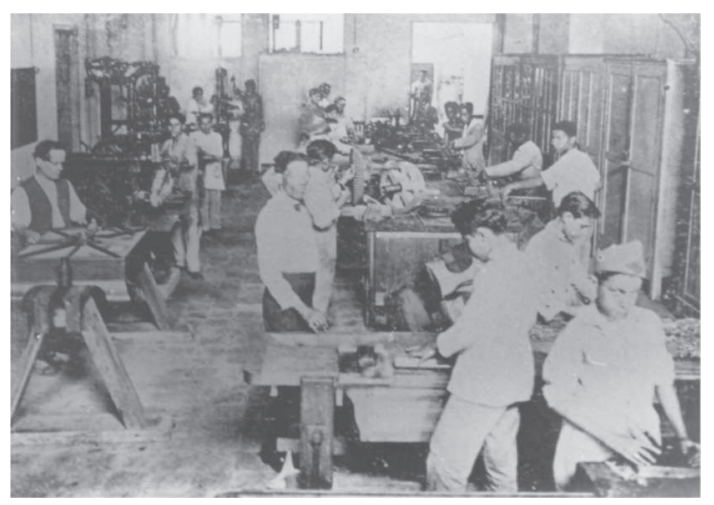

FIGURA 21 - Acervo do Clube de História do CEHL, data indeterminada, autor desconhecido. (Escola Profissional Washington Luís [?]). "Oficina de Madeira Seção de Modelação e Ajustagem”. 


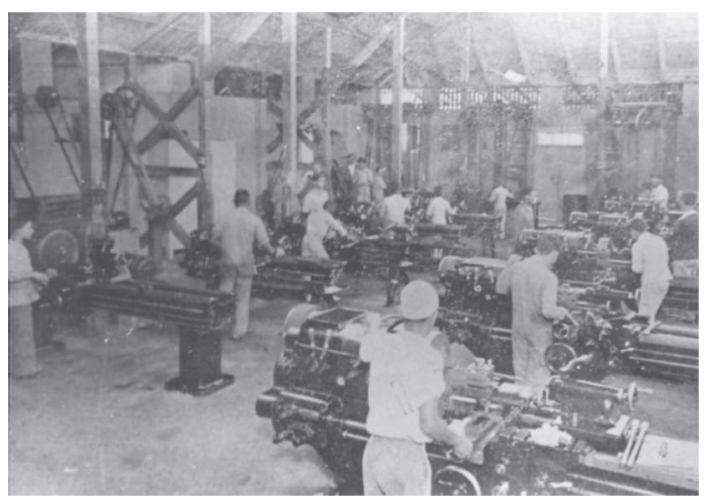

FIGURA 22 - Acervo do Clube de História do CEHL, data indeterminada, autor desconhecido. (Escola Profissional Henrique Lage ?]). "Oficina de Tornearia Mecânica”.

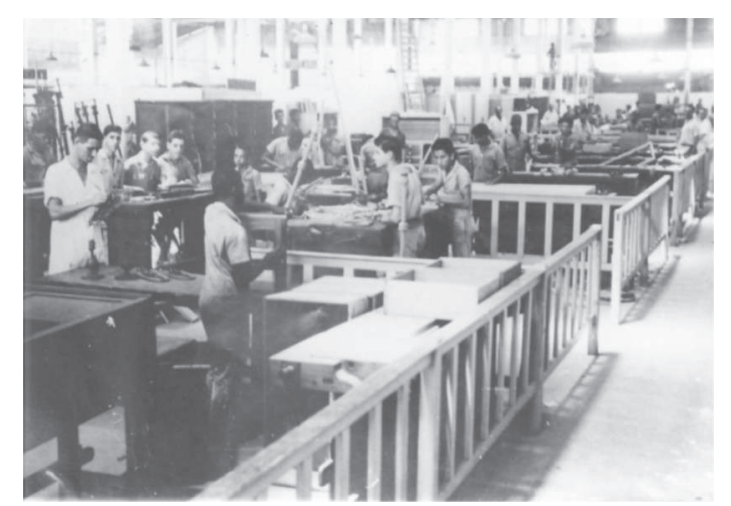

FIGURA 23 - Acervo do Clube de História do CEH 1948, autor desconhecido. (Escola Profissional Henrique Lage). "Oficina de Marcenaria".. 


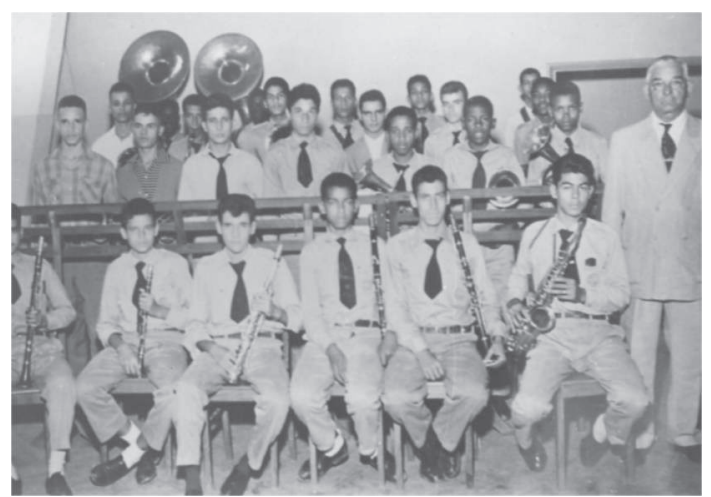

FIGURA 24 - Acervo do Clube de História do CEHL, 1948, autor desconhecido. (Escola Profissional Henrique Lage) "Alunos da Banda da Escola.”.

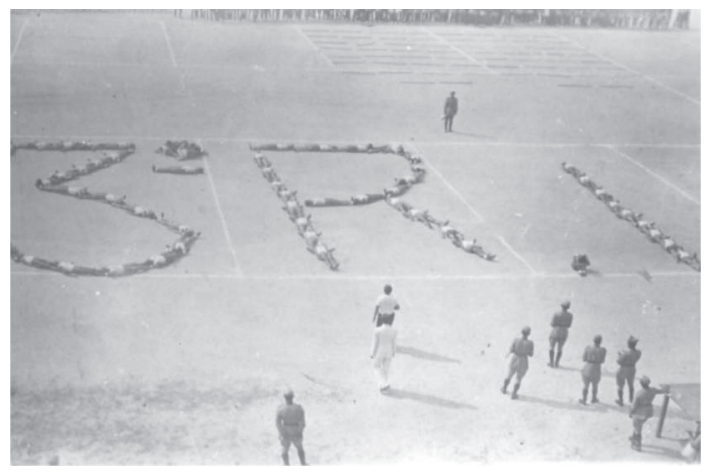

FIGURA 25 -. Acervo do Clube de História do CEHL, 1939, autor desconhecido. (Escola do Trabalho do Estado do Rio de Janeiro). "Solenidade cívica do $3^{\circ}$ Regimento de Infantaria com a participação de alunos.". 


\section{4. O Centro Federal de Educação Tecnológica de Química (1942)}

O Cefet Química é uma escola que lutou reiteradamente pela sua identidade e autonomia. Criada em fevereiro de 1942, foi implantada como Curso Técnico de Química Industrial nas dependências da Escola Nacional de Química da Universidade do Brasil, atual Universidade Federal do Rio de Janeiro. Em 1946 foi transferida para as dependências da Escola Técnica Nacional (ETN) - atual Centro Federal de Educação Tecnológica Celso Suckow da Fonseca (Cefet-RJ) - onde permaneceu 40 anos.

Seu crescimento se deu na luta por conservar-se autônoma e ter uma sede própria, o que somente veio a ocorrer em 1986. É uma instituição de vanguarda no ensino médio técnico e tecnológico de química, e acompanha o processo de desenvolvimento industrial e tecnológico do país. Vem migrando, progressivamente, para o ensino superior, à medida que muitos de seus docentes se qualificaram como mestres e doutores e, no momento, apoiado no que estimula a transformação dos Cefets em IFETS ou Institutos Superiores de Educação Tecnológica. ${ }^{11}$.

As fotos pertencem ao Centro de Memória do Cefet Química de Nilópolis, estado do Rio de Janeiro - Unidade Maracanã. No período 2003 a 2006, como parte da pesquisa (CIAVATTA, 2007), as fotografias dispersas em caixas, álbuns e envelopes começaram a ser coletadas, identificadas e classificadas pela Assessoria de Comunicação do Cefet. São cerca de 8.500 fotos, que versam sobre os diversos aspectos da vida escolar: edifícios, oficinas, laboratórios, feiras de ciência, jogos, certames de matemática e de xadrez, alunos, professores, atividades de música, teatro, shows, formaturas, evidenciando a transformação da escola, de seus espaços e equipamentos até os dias atuais (ROSA, 2006). A escola abre as portas para visitantes durante a realização da tradicional Semana de Química onde os estudantes expõem os projetos de ciências que desenvolvem durante o ano, alguns conjugados às atividades de artes, como a encenação de experimentos.

\footnotetext{
${ }^{11}$ Decreto n. 6.095 de 24 de abril de 2007. 


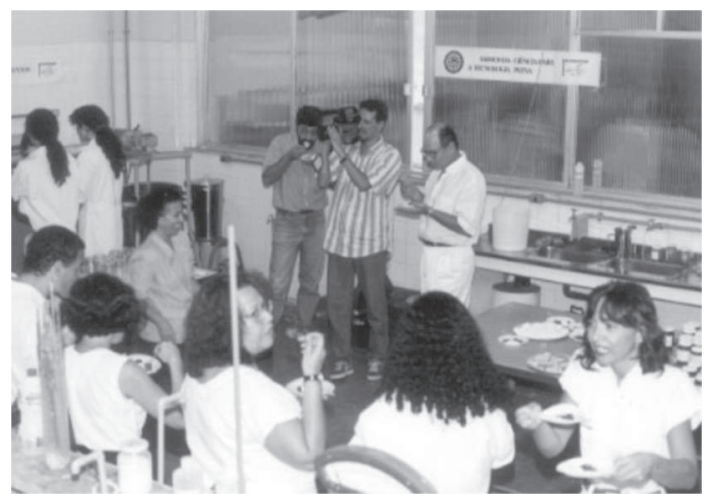

FIGURA 26 - Centro de Memória do Cefet de Química de Nilópolis, 1996, autor desconhecido. “Apresentação de Projeto realizado pelos alunos do Ensino Técnico, em 1996, XVII Semana de Química, no espaço do Laboratório de Alimentos".

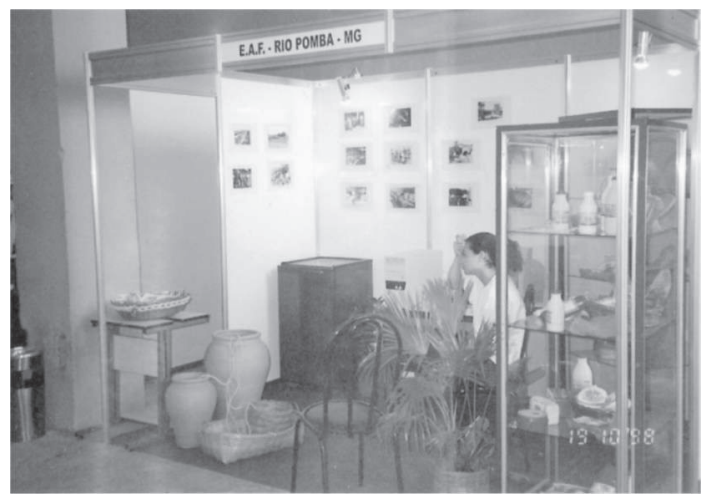

FIGURA 27 - Centro de Memória do Cefet de Química de Nilópolis, 1998, autor desconhecido. "Na XIX Semana de Química, iniciaram-se as semanas temáticas. A primeira teve como eixo condutor a 'A Agroindústria' 


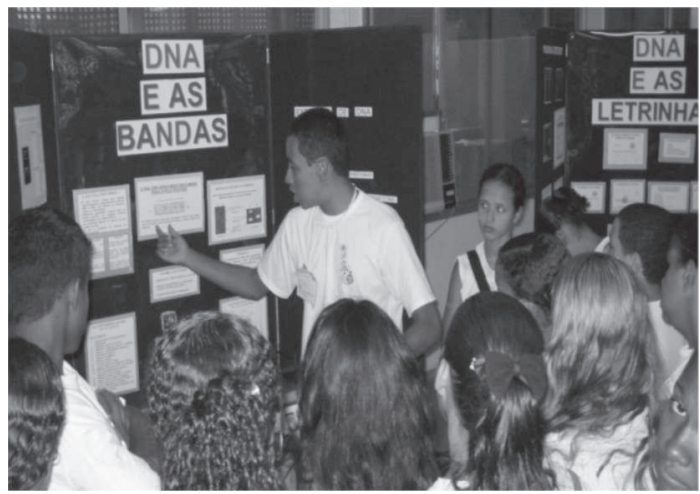

FIGURA 28 - Centro de Memória do Cefet de Química de Nilópolis, 2003, autor desconhecido. "Projeto DNA, Semana de Química de 2003, realizado pelos alunos do Ensino Médio e Técnico, orientado pela professora Martha Godinho, apresentando os conteúdos a alunos de escolas públicas"

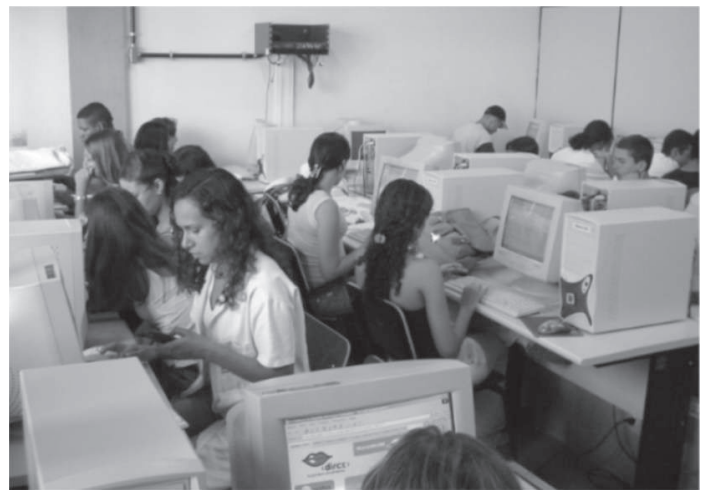

FIGURA 29 - Centro de Memória do Cefet Química, 2003, Rosângela Aquino da Rosa. "Laboratório de Informática - Unidade Nilópolis, RJ”. 


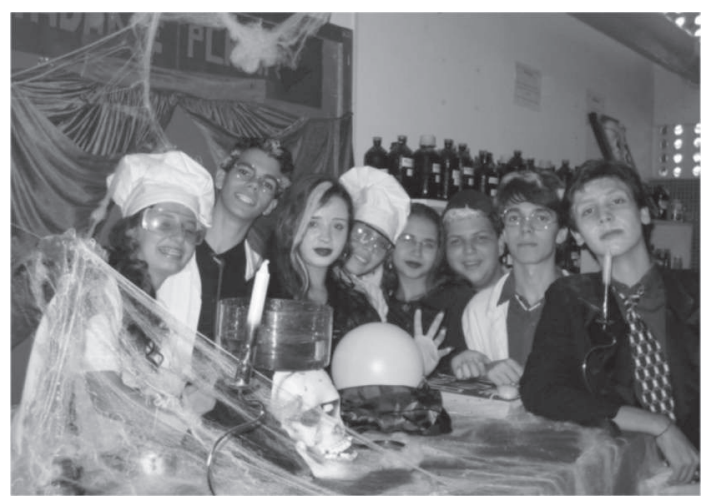

FIGURA 30 - Centro de Memória do Cefet de Química de Nilópolis, 2004, autor desconhecido. "Apresentação de Projeto ‘Química e Cotidiano', realizado pelos alunos do Ensino Médio e Técnico, orientado pelo professor Paulo Chagas".

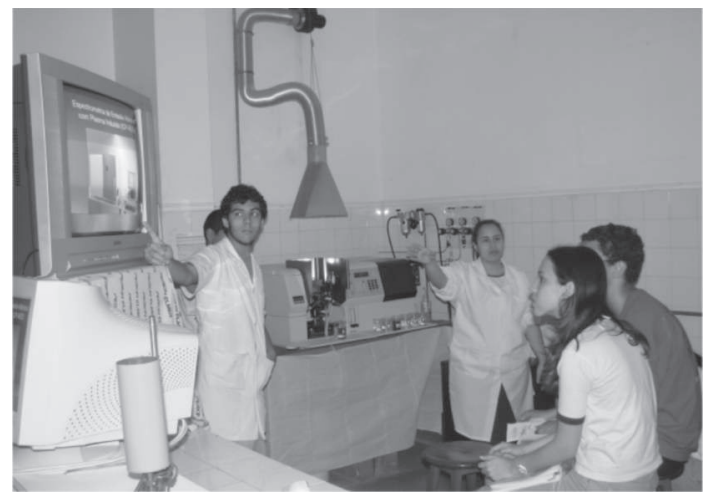

FIGURA 31 - Centro de Memória do Cefet Química, 2006, Rosângela Aquino da Rosa. "Laboratório de Análise Química Qualitativa - Unidade Maracanã”. 


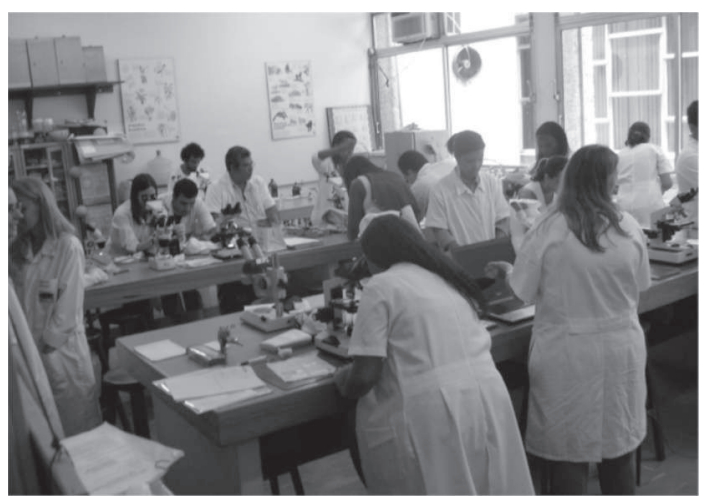

FIGURA 32 - Centro de Memória do Cefet Química, 2006, Rosângela Aquino da Rosa. "Laboratório de Biologia - Unidade Maracanã - Aula Prática. Ensino Médio Técnico"

\section{Considerações finais}

Há uma multiplicidade de tempos condensados na contemplação de uma fotografia: o tempo presente de quem contempla, o tempo das coisas fotografadas, o tempo do fotógrafo. $\mathrm{Na}$ análise do corpus documental de 95 fotografias das "escolas do trabalho", profissionais, técnicas e tecnológicas, devemos tentar lidar com a sua complexidade, buscando suas múltiplas relações sociais subjacentes (econômicas, políticas, científicas, tecnológicas, educacionais etc.).

Os três primeiros conjuntos de fotos, pertencentes às escolas mais antigas, não constituem um corpus iconográfico homogêneo, em razão de suas referências temporais ao longo da primeira metade do século passado, pela diversidade de autores das fotografias, pelos acervos diversos dos quais provêm e pelos conteúdos das mesmas.

Mas as fotos referem-se a contextos semelhantes no sentido de que as escolas eram, desde o tempo de sua fundação (1875, 1916 e 1923), destinadas a preparar "meninos desvalidos" e filhos de trabalhadores de bairros "proletários" para o trabalho, considerando as fotos datadas, $(30 \%$ delas), através da memória dos professores entrevistados - entre 70 e 80 anos ou mais de idade. Eles entraram para as escolas nos anos 1920 ou 1930 
e falam sobre suas experiências como de um tempo de boas lembranças, mas todos seguiram profissões diferentes dos ofícios manuais em que foram formados. Todos os entrevistados se tornaram professores das escolas.

$\mathrm{Na}$ maioria, são imagens que parecem representar a visão das autoridades ou do Estado educador, não só pela autoria de Malta, fotógrafo oficial da Prefeitura do Rio de Janeiro em $22 \%$ das fotos, mas também pelo predomínio absoluto da característica de "pose" e, às vezes, de "vítrine" de muitas das fotografias. Apenas algumas fotos da ETE Visconde de Mauá privilegiam o que poderia ser pensado como "o ponto de vista do professor".

No caso do Cefet Química, o trabalho com as fotos deu origem ao Centro de Memória do Cefet Química, ainda em processo de implantação e a uma dissertação de Mestrado (rosa, op. cit.), evidenciando a relação ciência e arte. $\mathrm{O}$ avanço das forças produtivas, em uma área estratégica como a química, e a educação técnica e tecnológica revelam-se nos detalhes dos instrumentos (computadores, microscópios e outros aparelhos de tecnologia avançada) e nas complexas atividades desenvolvidas pelos jovens. Não são mais escolas de ensino primário como as primeiras. Não se destinam apenas aos "desfavorecidos da fortuna" como nos primórdios da formação profissional no país. As escolas técnicas federais que se transformaram em Cefets e caminham para se institucionalizar como Ifets são, hoje, instituições de ensino médio e superior, altamente seletivas pela demanda crescente a qualidade e a gratuidade de seus cursos. Como outras instituições congêneres, o CEFET Química, pelo seu reconhecido padrão técnico e intelectual, é alvo de intensa disputa de vagas por jovens de todas as classes sociais.

\section{Referências}

ANDERSON, Perry. A crise da crise do marxismo. São Paulo: Brasiliense, 1985 BARRA, Valdeniza M. Lopes da. Possíveis relações entre aspectos materiais (espaço, mobiliário e utensílios), modos de organização da escola e intervenções de ensino. Revista Brasileira de História da Educação, SBHE, n 14, maio/agosto 2007, p. 15-36.

BRAUDEL, Ferdinand. A longa duração. In: . História e ciências sociais. Lisboa: Presença, 1992. 
CHARTIER, Roger. A história cultural: entre práticas e representações. Lisboa: Difel, 2002.

CIAVATTA FRANCO, Maria. A Escola do Trabalho. História e imagens. (Tese de Professor Titular - Trabalho e Educação). Niterói: UFF, 1993.

O trabalho como princípio educativo. Uma investigação teóricometodológica (1930-1960). Tese (Doutorado em Ciências Humanas Educação. Rio de Janeiro, Depto. de Educação, Pontifícia Universidade Católica do Rio de Janeiro, 1990.

CIAVATTA, Maria, LEITE, Sidney Q. M. e ROSA, Rosângela A.da. Ciência e arte: o resgate da memória através da fotografia da educação profissional e tecnológica. In: CIAVATTA, Maria (Coord.). Memória e temporalidades do trabalho e da educação. Rio de Janeiro: Lamparina / FAPERJ, 2007.

(Coord.). Memória e temporalidades do trabalho e da educação. Rio de Janeiro: Lamparina / FAPERJ, 2007.

. O mundo do trabalho em imagens - A fotografia como fonte histórica (Rio de Janeiro, 1900-1930). Rio de Janeiro: DP \& A, 2002.

CURY, Jamil R. Educação e contradição. São Paulo: Cortez/Autores Associados, 1985.

FERREIRA, Marieta de Moraes e AMADO, Janaína. Usos e abusos da história oral. Rio de Janeiro: FGV, 1996

FISCARELLI, Rosilene B. de O; SOUZA, Rosa F. de. Símbolos de Excelência Escolar: história e memória da escola pública inscrita em troféus. Revista Brasileira de História da Educação, SBHE, n 14, maio/ agosto 2007, p. 95-116.

FRIGOTTO, Gaudêncio, CIAVATTA, Maria; RAMOS, Marise. A gênese do Decreto n. 5.154/04: um debate no contxto controverso da democracia restrita. In: __ Ensino médio integrado. Concepção e contradições. São Paulo: Cortez, 2005.

KONDER, L. O futuro das filosofia da práxis. Petrópolis, RJ. Vozes, 1992

KOSSOY, Boris. Fotografia e história. São Paulo: Ática, 1989. 
LABASTIDA, Jayme. O objeto da história. Nova escrita, Ensaio, São Paulo, 5 (11/12): 161-175, 1983.

LE GOFF, Jacques. A história nova. São Paulo: Martins Fontes, 1990.

ROSA, Rosângela A. da Resgate da memória de projetos discentes de uma instituição federal de educação profissional e tecnológica através da fotografia: aspectos de ciência e arte. Dissertação (Mestrado em Biociências e Saúde). Rio de Janeiro: Fiocruz, 2006.

SOUZA, Gisele de. Cultura escolar na história da instrução política primária no Paraná: anotações de uma trajetória de pesquisa. Revista Brasileira de História da Educação, SBHE, n 14, maio/agosto 2007, p. 37-68.

SOUZA, Regina Maria S. A cultura escolar da Deutsche Schule. Revista Brasileira de História da Educação, SBHE, n 14, maio/agosto 2007a, p. 69-94.

Data de registro: $15 / 02 / 09$

Data de aceite: 18/03/09 
